\title{
Exploring the role of sigma factor gene expression on production by Corynebacterium glutamicum: sigma factor $\mathrm{H}$ and FMN as example
}

\author{
Hironori Taniguchi and Volker F. Wendisch* \\ Genetics of Prokaryotes, Faculty of Biology and Center for Biotechnology, Bielefeld University, Bielefeld, Germany
}

\section{OPEN ACCESS}

Edited by:

Bettina Siebers,

University of Duisburg-Essen,

Germany

Reviewed by:

Shawn Chen,

Ohio University, USA

Grzegorz Wegrzyn,

University of Gdansk, Poland

*Correspondence:

Volker F. Wendisch,

Genetics of Prokaryotes, Faculty

of Biology and Center

for Biotechnology, Bielefeld University,

Universitätsstraße 25,

33501 Bielefeld, Germany

volker.wendisch@uni-bielefeld.de

Specialty section:

This article was submitted to Microbiotechnology, Ecotoxicology

and Bioremediation,

a section of the journal

Frontiers in Microbiology

Received: 19 May 2015

Accepted: 06 July 2015

Published: 22 July 2015

Citation:

Taniguchi H and Wendisch VF (2015)

Exploring the role of sigma factor

gene expression on production by

Corynebacterium glutamicum: sigma

factor $\mathrm{H}$ and $F M N$ as example.

Front. Microbiol. 6:740

doi: 10.3389/fmicb.2015.00740
Bacteria are known to cope with environmental changes by using alternative sigma factors binding to RNA polymerase core enzyme. Sigma factor is one of the targets to modify transcription regulation in bacteria and to influence production capacities. In this study, the effect of overexpressing each annotated sigma factor gene in Corynebacterium glutamicum WT was assayed using an IPTG inducible plasmid system and different IPTG concentrations. It was revealed that growth was severely decreased when sigD or sigH were overexpressed with IPTG concentrations higher than $50 \mu \mathrm{M}$. Overexpression of sigH led to an obvious phenotypic change, a yellowcolored supernatant. High performance liquid chromatography analysis revealed that riboflavin was excreted to the medium when sigH was overexpressed and DNA microarray analysis confirmed increased expression of riboflavin biosynthesis genes. In addition, genes for enzymes related to the pentose phosphate pathway and for enzymes dependent on flavin mononucleotide (FMN), flavin adenine dinucleotide (FAD), or NADPH as cofactor were upregulated when sigH was overexpressed. To test if sigH overexpression can be exploited for production of riboflavin-derived FMN or FAD, the endogenous gene for bifunctional riboflavin kinase/FMN adenyltransferase was Coexpressed with sigH from a plasmid. Balanced expression of sigH and ribF improved accumulation of riboflavin $(19.8 \pm 0.3 \mu \mathrm{M})$ and allowed for its conversion to FMN $(33.1 \pm 1.8 \mu \mathrm{M})$ in the supernatant. While a proof-of-concept was reached, conversion was not complete and titers were not high. This study revealed that inducible and gradable overexpression of sigma factor genes is an interesting approach to switch gene expression profiles and to discover untapped potential of bacteria for chemical production.

\section{Keywords: Corynebacterium, RNA polymerase sigma factor, sigH, ribA, riboflavin, FMN production}

\section{Introduction}

The sigma factor is a component of RNA polymerase holoenzyme and is important to recognize the promoter sequence in transcription initiation (Vassylyev et al., 2002; Feklístov et al., 2014). In general, a bacterium possesses two or more sigma factor genes and RNA polymerase holoenzymes with different sigma factors recognize distinct promoter sequences (Paget and Helmann, 2003; 
Staron et al., 2009). Upon environmental stress the vegetative sigma factor may be replaced by an alternative sigma factor, a mechanism wide-spread in bacteria to cope with environmental changes (Kazmierczak et al., 2005; Sharma and Chatterji, 2010). This fundamental mechanism of transcriptional regulation has recently drawn attention as a candidate of metabolic engineering for global transcriptional engineering (Tripathi et al., 2014).

Corynebacterium glutamicum was isolated as a glutamateproducing organism in 1956 and has been used for the large scale production of glutamate and lysine for more than five decades (Eggeling and Bott, 2005, 2015; Burkovski, 2008; Yukawa and Inui, 2013). Amino acid producing strains have been developed based on random mutagenesis and/or rational engineering. For instance, this bacterium has been engineered to produce amino acids such as L-serine (Peters-Wendisch et al., 2005), L-isoleucine (Morbach et al., 1996), L-valine (Radmacher et al., 2002; Blombach et al., 2007), L-proline (Jensen and Wendisch, 2013), L-tryptophan (Ikeda and Katsumata, 1999), L-citrulline (Eberhardt et al., 2014), or L-arginine (Park et al., 2014). It has been also engineered to produce precursors of amino acids such as 2-ketoisovalerate (Krause et al., 2010) and 2ketoisocaproate (Bückle-Vallant et al., 2014; Vogt et al., 2015) or amino acid-derived compounds such 1,4-diaminobutane (Schneider and Wendisch, 2010; Schneider et al., 2012) or 1,5diaminopentane (Mimitsuka et al., 2007). Metabolic engineering focused mainly on amino acid biosynthesis, precursor supply, cofactor regeneration and amino acid transport. Concerning regulatory engineering, mainly feedback-resistant versions of key enzymes are in use, however, also transcriptional regulatory engineering has been applied, e.g., by deletion of the genes encoding pathway-specific regulators such as LbtR (BückleVallant et al., 2014) or ArgR (Hwang et al., 2008) or higher order regulators such as SugR (Blombach et al., 2009). However, global regulatory engineering using sigma factor genes has not yet been explored.

C. glutamicum WT possesses seven sigma factor genes encoded on its chromosome (Kalinowski et al., 2003). These sigma factors are classified into group 1 (SigA), group 2 (SigB) and group 4 (SigC, SigD, SigE, SigH, SigM) according to their conserved structures. C. glutamicum lacks group 3 type sigma factors (Pátek and Nešvera, 2011). The regulons of some of these sigma factors have been studied, e.g., for SigA, SigB, SigE, SigH, and SigM. SigA is the principle sigma factor and related to the transcription initiation of housekeeping genes (PfeiferSancar et al., 2013). The gene sigA is essential in C. glutamicum as well as in other bacteria (Pátek and Nešvera, 2011). SigB is related to the general stress response and assumed to play an important role at the transition from the exponential to the stationary growth phase (Larisch et al., 2007). Analysis of the sigB deletion mutant revealed that SigB is involved in glucose metabolism under oxygen deprivation conditions, thymidylate synthesis and protein secretion (Ehira et al., 2008; Cho et al., 2012; Watanabe et al., 2013). The functions of SigC and SigD have not yet been elucidated. SigE is related to surface stress and its activity is repressed by anti-sigma factor CseE (Park et al., 2008). SigH is involved in the response to heat shock, $\mathrm{pH}$ stress and disulfide/oxidative stress (Kim et al., 2005a; Ehira et al., 2008; Barriuso-Iglesias et al., 2013), and its activity is repressed by anti-sigma factor RshA (Busche et al., 2012). Recently, SigH-dependent promoters were studied by ChIP-chip analysis (Toyoda et al., 2015). SigM is involved in transcription of disulfide stress related genes (Nakunst et al., 2007).

In this study, the effects of graded sigma factor gene overexpression on C. glutamicum have been characterized. Based on the finding that sigH overexpression resulted in riboflavin production, flavin mononucleotide (FMN) producing C. glutamicum strains have been constructed.

\section{Materials and Methods}

\section{Bacterial Strains, Plasmid, and Primer}

The strains, plasmids and oligonucleotides used in this work are listed in Table 1. Plasmids were constructed based on pEKEx3 and pVWEx1, IPTG inducible Escherichia coli - C. glutamicum shuttle vectors (Peters-Wendisch et al., 2001; Stansen et al., 2005). The DNA sequence of sigma factor gene was amplified from genomic DNA of C. glutamicum WT by polymerase chain reaction (KOD, Novagen, Darmstadt, Germany) with respective primer pairs in Table 1. The PCR product was inserted into BamHI-digested pEKEx3 or pVWEx1 plasmid by Gibson assembly (Gibson et al., 2009). E. coli DH5 $\alpha$ was used for cloning. E. coli competent cells were transformed by heat shock method (Sambrook, 2001) or by electroporation method (Nováková et al., 2014). All cloned DNA fragments were confirmed to be correct by sequencing. C. glutamicum competent cells were transformed by electroporation at $2.5 \mathrm{kV}, 200 \Omega$, and $25 \mu \mathrm{F}$ (van der Rest et al., 1999; Eggeling and Bott, 2005).

\section{Medium and Growth Condition}

C. glutamicum was precultured in BHI or LB medium overnight, washed once with CGXII medium (Eggeling and Bott, 2005) without carbon source and inoculated in CGXII with $222 \mathrm{mM}$ of glucose at initial OD at $600 \mathrm{~nm}$ of 1 . The OD was measured with UV-1202 spectrophotometer (Shimadzu, Duisburg, Germany) with suitable dilutions. When appropriate, $100 \mu \mathrm{g} / \mathrm{mL}$ of spectinomycin, $25 \mu \mathrm{g} / \mathrm{mL}$ of kanamycin and IPTG were

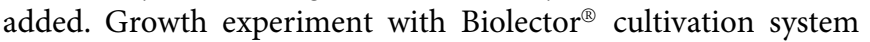
(m2pLabs, Baesweiler, Germany) was performed in $1 \mathrm{~mL}$ of CGXII using FlowerPlate ${ }^{\circledR}$ (m2pLabs, Baesweiler, Germany) at $30^{\circ} \mathrm{C}, 1,100 \mathrm{rpm}$. Cell growth was monitored online every $10 \mathrm{~min}$ for $48 \mathrm{~h}$. Maximum growth rate $\mu\left(\mathrm{h}^{-1}\right)$ was calculated from 20 measuring points of arbitrary unit of backscattering light $(620 \mathrm{~nm})$. Plate image was scanned with Perfection V750-M Pro scanner (Epson, Ludwigshafen am Rhein, Germany). Color balance of blue against yellow was set to +70 .

\section{Riboflavin Production Experiments}

Riboflavin production experiments were performed at $30^{\circ} \mathrm{C}$, $120 \mathrm{rpm}$ in $50 \mathrm{~mL}$ of GCXII with $222 \mathrm{mM}$ of glucose and $15 \mu \mathrm{M}$ of IPTG using $500 \mathrm{~mL}$ baffled flasks. Supernatant was separated by centrifugation after $48 \mathrm{~h}$ of cultivation. Riboflavin concentration of cell-free supernatant was analyzed 
TABLE 1 | Bacterial strains, plasmids and oligonucleotides used in this study.

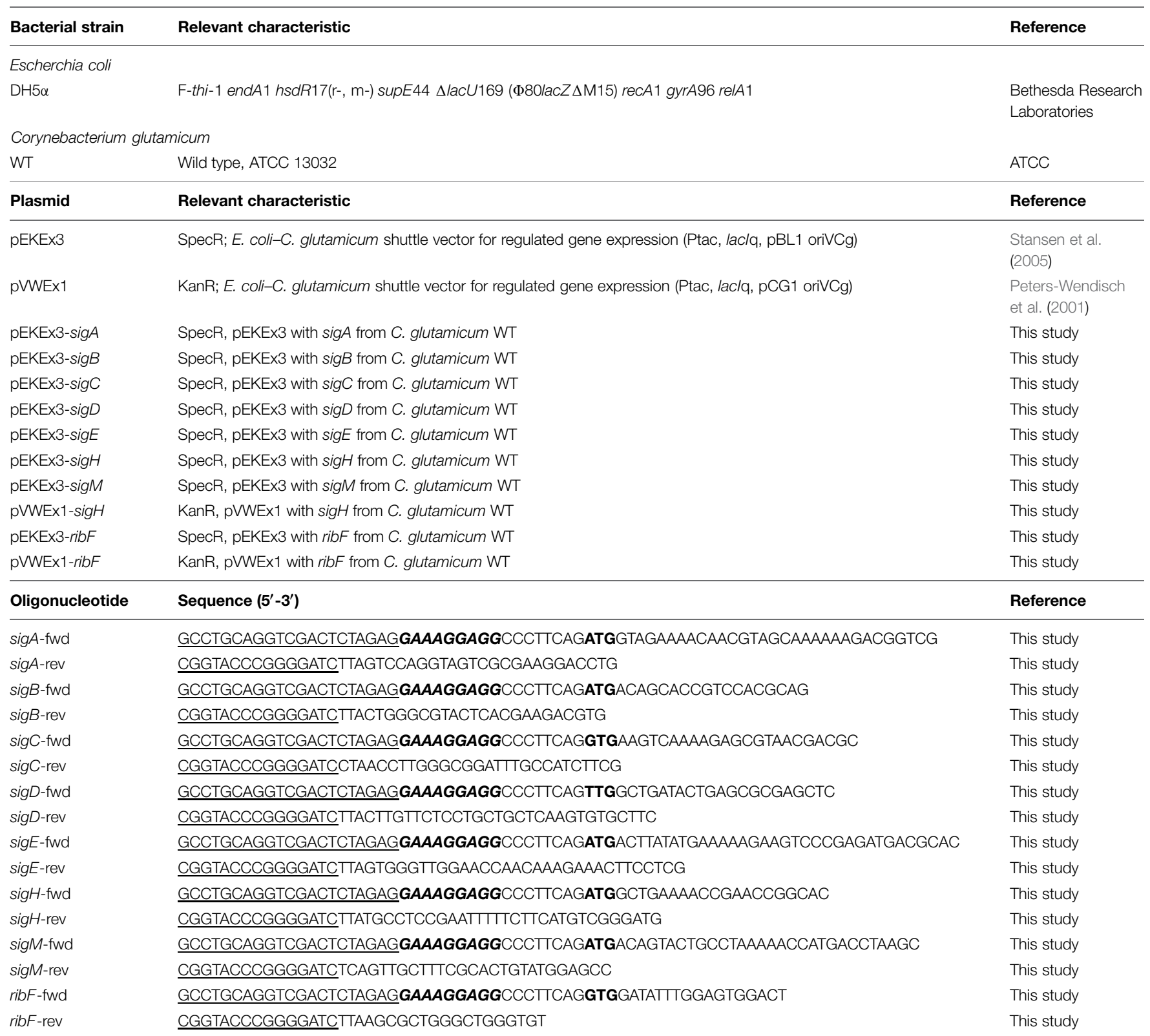

Underlined sequences represent the overlap region with vector plasmid; sequences in bold italic represent ribosome binding sites; sequences in bold represents the translational start codons.

using high performance liquid chromatography (HPLC; Agilent Technologies Sales \& Services GmbH \& Co. KG, Waldbronn, Germany). The confirmation and quantification of riboflavin was performed using diode array detector (DAD). Samples were separated with a column system consisting of a precolumn (LiChrospher 100 RP18 EC-5 $\mu(40 \mathrm{~mm} \times 4 \mathrm{~mm})$, CSChromatographie Service GmbH, Langerwehe, Germany) and a main column (LiChrospher $100 \mathrm{RP} 18 \mathrm{EC}-5 \mu(125 \mathrm{~mm} \times 4 \mathrm{~mm})$, CS Chromatographie Service GmbH, Langerwehe, Germany) with $0.1 \mathrm{M}$ sodium acetate, $\mathrm{pH} 7.2$ supplemented with $0.03 \%$ sodium azide (A) and methanol (B) as the mobile phase. The following gradient was used at a flow rate of $1.2 \mathrm{~mL} / \mathrm{min} ; 0 \mathrm{~min}$
B: $20 \%, 0.5 \mathrm{~min}$ B: $38 \%, 2.5 \min$ B: $46 \%, 3.7 \mathrm{~min}$ B: $65 \%, 5.5 \mathrm{~min}$ B: $70 \%, 6 \min$ B: $75 \%, 6.2 \min$ B: $85 \%, 6.7 \min$ B: $20 \%, 8.9 \min$ B: $20 \%$.

\section{Transcriptome Analysis of sigH Overexpressing Strain using DNA Microarrays}

C. glutamicum strains WT(pEKEx3) and WT(pEKEx3-sigH) were cultured in BHI medium and inoculated into CGXII medium with $222 \mathrm{mM}$ of glucose for adaptation. Cells were cultured overnight and inoculated into $50 \mathrm{~mL}$ of CGXII medium with $222 \mathrm{mM}$ of glucose and 10 or $15 \mu \mathrm{M}$ of IPTG at the initial OD of 1 . Cells were harvested in the early exponential growth 
phase (OD between 6 and 8) and RNA isolation was performed as described previously (Wendisch, 2003). The purified RNA was analyzed by spectrophotometer (NanoDrop) for quantity and gel electrophoresis for quality. The RNA sample was stored at $-80^{\circ} \mathrm{C}$ until further use. cDNA synthesis from total RNA as well as DNA microarray hybridization were performed as described previously (Netzer et al., 2004; Polen et al., 2007). Normalization and evaluation of the microarray data was done with the software package EMMA 2 (Dondrup et al., 2009). Genes which were upregulated in WT(pEKEx3-sigH) under both 10 and $15 \mu \mathrm{M}$ of IPTG concentration were taken into account for further analysis $(p$-value $<0.05, M$-value $>1)$.

\section{Measurement of Glucose-6-Phosphate 1-Dehydrogenase Enzyme Activities}

Enzyme activities of glucose-6-phosphate 1-dehydrogenase in C. glutamicum WT (pEKEx3) and C. glutamicum WT(pEKEx3sigH) were measured in cell free crude extracts, which were prepared as described previously (Stansen et al., 2005) with some modification. Shortly, cells grown in CGXII medium with $222 \mathrm{mM}$ of glucose and $15 \mu \mathrm{M}$ of IPTG were harvested in the exponential growth phase (OD around 6), washed once with disruption buffer (50 mM Tris- $\mathrm{HCl} \mathrm{pH} 8.5,10 \mathrm{mM} \mathrm{MgCl}_{2}$, and $1 \mathrm{mM} \mathrm{DTT}$ ) and stored at $-20^{\circ} \mathrm{C}$ until use. Protein concentrations were determined with the Bradford reagent using bovin serum albumin as a standard. Enzyme activities were measured spectrophotometrically following NADPH formation at $30^{\circ} \mathrm{C}$ in final volume of $1 \mathrm{~mL}$. The concomitant formation of NADPH was measured at $340 \mathrm{~nm}$ and absorption coefficient of $6.3 \mathrm{mM}^{-1} \mathrm{~cm}^{-1}$ at $340 \mathrm{~nm}$ was used for calculating enzyme activities. The assay contained $50 \mathrm{mM}$ Tris- $\mathrm{HCl} \mathrm{pH} 8.5,10 \mathrm{mM}$ $\mathrm{MgCl}_{2}, 100 \mathrm{mM} \mathrm{NADP}^{+}$and $100 \mathrm{mM}$ glucose-6-phosphate.

\section{FMN and FAD Production Experiments}

FMN and FAD production experiment was performed at $30^{\circ} \mathrm{C}$ with $120 \mathrm{rpm}$ in $50 \mathrm{~mL}$ of GCXII with $222 \mathrm{mM}$ of glucose using $500 \mathrm{~mL}$ baffled flasks. $100 \mu \mathrm{M}$ of IPTG was added after OD reached around 10. Supernatant was separated by centrifugation after $48 \mathrm{~h}$ of cultivation. FMN and FAD concentration of cellfree supernatant was analyzed as described previously with some modifications (Barile et al., 1997). Shortly, signal was detected with fluorescent detector (FLD; excitation and emission wavelengths of 450 and $520 \mathrm{~nm}$, respectively) and samples were separated with the same column systems used in riboflavin production experiments with $20 \mathrm{mM}$ potassium phosphate, $\mathrm{pH}$ 6.0 (A) and methanol (B) as the mobile phase. The following ratio was used at a flow rate of $1.0 \mathrm{~mL} / \mathrm{min} ; 0-5 \mathrm{~min} \mathrm{B:} \mathrm{25 \% ,} \mathrm{5-10} \mathrm{min}$ B: $50 \%$.

\section{Results}

\section{Effect of Overexpressing Sigma Factor Genes in C. glutamicum}

To investigate the influence of overexpressing sigma factor genes in C. glutamicum, each sigma factor gene ( $\operatorname{sig} A, \operatorname{sig} B, \operatorname{sig} C, \operatorname{sig} D$, $\operatorname{sig} E$, sigH, and $\operatorname{sigM}$ ) was cloned into IPTG-inducible expression vector $\mathrm{pEKEx} 3$ and transformed into C. glutamicum WT. Growth of these strains and of a control strain containing the empty vector pEKEx3 was monitored in the presence of different IPTG concentrations $(0,5,15,50$, or $250 \mu \mathrm{M})$ in CGXII medium containing $222 \mathrm{mM}$ of glucose. Growth of the control strains was not affected by IPTG, while sigma factor gene transformants grew with lower growth rates at higher IPTG concentrations. In particular, sigD and sigH transformants exhibited strongly reduced growth rates with 50 and $250 \mu \mathrm{M}$ IPTG and did not reach the stationary phase during $48 \mathrm{~h}$ of cultivation (Figure 1A). Interestingly, the cultures of the sigH transformant with up to $15 \mu \mathrm{M}$ IPTG were colored yellow (Figure 1B). Therefore, the supernatants of all cultures were analyzed by recording absorbance spectra from 350 to $600 \mathrm{~nm}$ (Figure 2). While absorbance of the different supernatants varied to some degree when comparing the different transformants, the supernatant of sigH transformant induced with $10 \mu \mathrm{M}$ IPTG showed a strong absorbance centered at about $450 \mathrm{~nm}$. Since the sigH transformant did not grow when induced with higher IPTG concentrations, this absorbance peak was not observed under these conditions.

\section{Overexpression of sigH Resulted in Riboflavin Secretion}

To verify the yellow color phenotype of WT(pEKEx3-sigH) in a different cultivation setting, this strain was grown in shake flasks and induced with $15 \mu \mathrm{M}$ IPTG immediately after inoculation. The cultures in shake flasks and the supernatants showed yellow color. Spectrophotometric analysis of the supernatant from the culture of $\mathrm{WT}(\mathrm{pEKEx} 3-s i g H)$ revealed maximal absorption at $450 \mathrm{~nm}$ as well as yellow fluorescence under UV irradiation (data not shown). Since the spectral properties of riboflavin fit well to those observed here, the supernatant and riboflavin as standard were analyzed by HPLC. Co-elution at around $3.2 \mathrm{~min}$ of riboflavin with the compound in the supernatant of WT(pEKEx3-sigH; Figure 3A) and comparable absorption spectra (300-550 nm; Figure 3B) revealed that riboflavin was produced by C. glutamicum WT(pEKEx3-sigH). No other significant peak was detected. Quantification based on a series of suitable riboflavin concentrations indicated that the accumulation of riboflavin in the supernatant of WT(pEKEx3$\operatorname{sigH})$ was about seven times as high as that of control strain WT(pEKEx3), $(68.0 \pm 1.3 \mu \mathrm{M}$ and $10.4 \pm 1.5 \mu \mathrm{M}$, respectively, biological triplicates). When expression of sigH was induced by addition of $100 \mu \mathrm{M}$ of IPTG in the middle of the exponential growth phase $(\mathrm{OD} \sim 10$ ) about $35 \mu \mathrm{M}$ riboflavin accumulated (Figure 4).

\section{Global Gene Expression Changes due to sigH Overexpression}

To determine if sigH overexpression affects riboflavin biosynthesis genes, DNA microarray experiments with C. glutamicum WT(pEKEx3-sigH) were performed and global gene expression at two different IPTG concentrations (10 and $15 \mu \mathrm{M})$ was compared to the control strain WT(pEKEx3). Statistically significant gene expression increases of at least two fold were observed for 193 and 142 genes, respectively, 


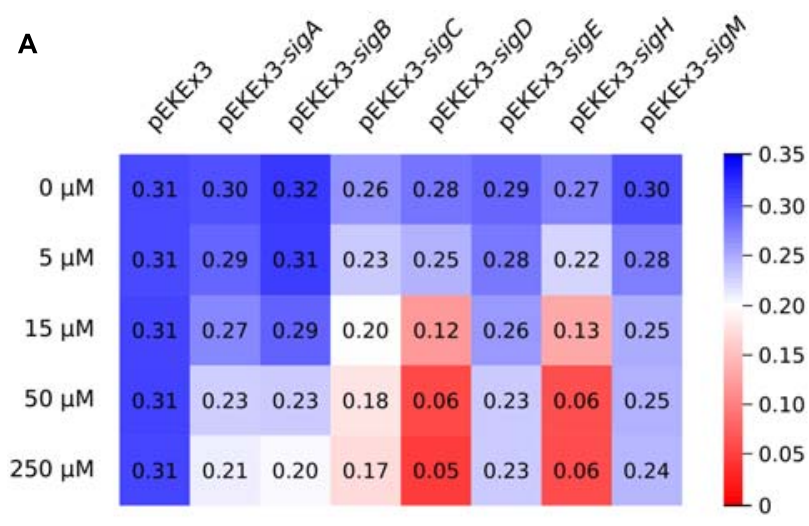

FIGURE 1 | Maximum growth rates of cultivations of C. glutamicum wild type (WT) transformed with plasmids for overexpression of various sigma factor genes (A) and images of these cultures taken after $48 \mathbf{h}$ of cultivation (B). CGXII with $222 \mathrm{mM}$ of glucose was used

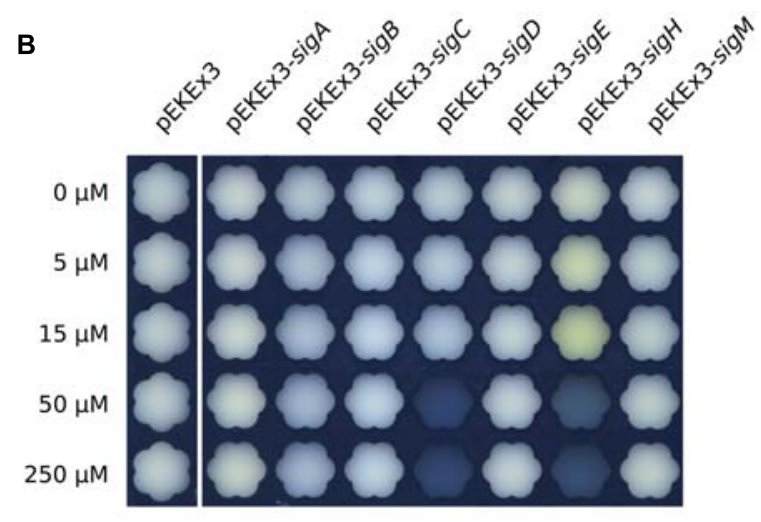

as growth medium. The different IPTG concentrations used to induce sigma factor gene overexpression are indicated. The growth rates $\left(\mathrm{h}^{-1}\right)$ depicted in (A) are color-coded from red to blue according to the given scale. upon induction with 10 and $15 \mu \mathrm{M}$ of IPTG $(M$-value $>1$, $p$-value $<0.05$; Table 2 ). Fifty genes were considered further as they were upregulated in both IPTG concentrations. Among these, genes related to riboflavin synthesis $[\mathrm{ribH}$ (cg1797), ribA (cg1798), ribC (cg1799)] and the pentose phosphate pathway [zwf (cg1778), opcA (cg1779)] were found. In addition, many genes encoding NADPH-dependent or FAD/FMN-dependent oxidoreductases were upregulated upon sigH overexpression (Table 2)

To confirm the observed gene expression changes of $z w f$ and $o p c A$, the specific enzyme activity of glucose-6-phosphate dehydrogenase encoded by $z w f$ and $o p c A$ was measured. The specific activity of glucose-6-phosphate dehydrogenase in the crude extracts of C. glutamicum WT(pEKEx3-sigH) was three times as high as in those of C. glutamicum WT(pEKEx3) (117 \pm 7 and $35 \pm 4 \mathrm{mU} / \mathrm{mg}$, respectively, biological triplicates). Thus, sigH overexpression led to increased $z w f$ and opcA mRNA level and increased specific activity of the encoded glucose-6phosphate dehydrogenase.

\section{FMN Production by C. glutamicum Established as Proof-of-Concept based on Overexpression of Endogenous Genes sigH and ribF}

Riboflavin is the precursor of FMN (flavin mononucleotide) and FAD (flavin adenine dinucleotide), which are biologically important as redox cofactor for many flavoenzymes and have an advantage as food additives over riboflavin due to much higher solubility in water (Kirk-Othmer, 1984). C. glutamicum possesses one gene, $r i b F$ (cg2169), encoding putative bifunctional riboflavin kinase / FMN adenylyltransferase, which converts riboflavin to FMN and FAD. In C. glutamicum, ribF is located about $350 \mathrm{~kb}$ downstream of the def2-fmt-fmu-rpe-ribGACH operon that contains the riboflavin biosynthesis genes $r i b G$, ribA, $r i b C$, and $r i b H$. Since the $r i b F$ mRNA level was not affected notably by sigH overexpression (Table 2), simultaneous overexpression of $r i b F$ and sigH was tested. However, severely retarded growth was observed already with only $15 \mu \mathrm{M}$ IPTG (data not shown). Therefore, expression of $\mathrm{ribF}$ or/and $\operatorname{sigH}$ was induced in the middle of the exponential growth phase (OD 10) using two compatible IPTG inducible plasmids, pEKEx3 and pVWEx1, with $100 \mu \mathrm{M}$ of IPTG. After $48 \mathrm{~h}$, neither riboflavin, FMN nor FAD were detected $(<5 \mu \mathrm{M})$ in the supernatants of the control strain carrying the empty vectors. Expression of only ribF from pVWEx1 did not result in accumulation of riboflavin, FMN nor FAD. When only sigH was overexpressed from plasmid pEKEx3 riboflavin was secreted to the medium $(32.4 \pm 1.8 \mu \mathrm{M})$, but neither FMN nor FAD accumulated (Figure 4). However, when both genes were overexpressed in C. glutamicum WT(pEKEx3-sigH, pVWEx1-ribF) secretion of FMN $(17.0 \pm 0.6 \mu \mathrm{M})$ in addition to riboflavin $(11.8 \pm 0.4 \mu \mathrm{M})$ was detected, while FAD was not detected $(<5 \mu \mathrm{M})$. To test if a different gene dosage affects $\mathrm{FMN}$ production, sigH was expressed from low copy number plasmid pVWEx1 and ribF from medium copy number plasmid pEKEx3. C. glutamicum WT(pEKEx3-ribF, pVWEx1-sigH) accumulated about two times higher concentrations of riboflavin $(19.8 \pm 0.3 \mu \mathrm{M})$ and FMN $(33.1 \pm 1.8 \mu \mathrm{M})$.

\section{Discussion}

In this study the potential of overexpressing sigma factor genes for metabolic engineering of C. glutamicum was tested. Sigma factors are related to the promoter selectivity during transcription initiation and are expected to affect expression of larger groups of genes, e.g., RpoS of $E$. coli regulates 481 genes under different growth and stress conditions (Weber et al., 2005). However, there are examples of sigma factors relevant for expression of only few genes, e.g., FecI of E. coli that is involved in expression of only seven genes (Cho et al., 2014). The functions of the seven sigma factors of C. glutamicum, which for comparison possesses 127 DNA-binding transcriptional regulators (Brune et al., 2005), have not been studied in detail although SigB, SigE, SigH, and SigM have been studied by several groups (Kim 


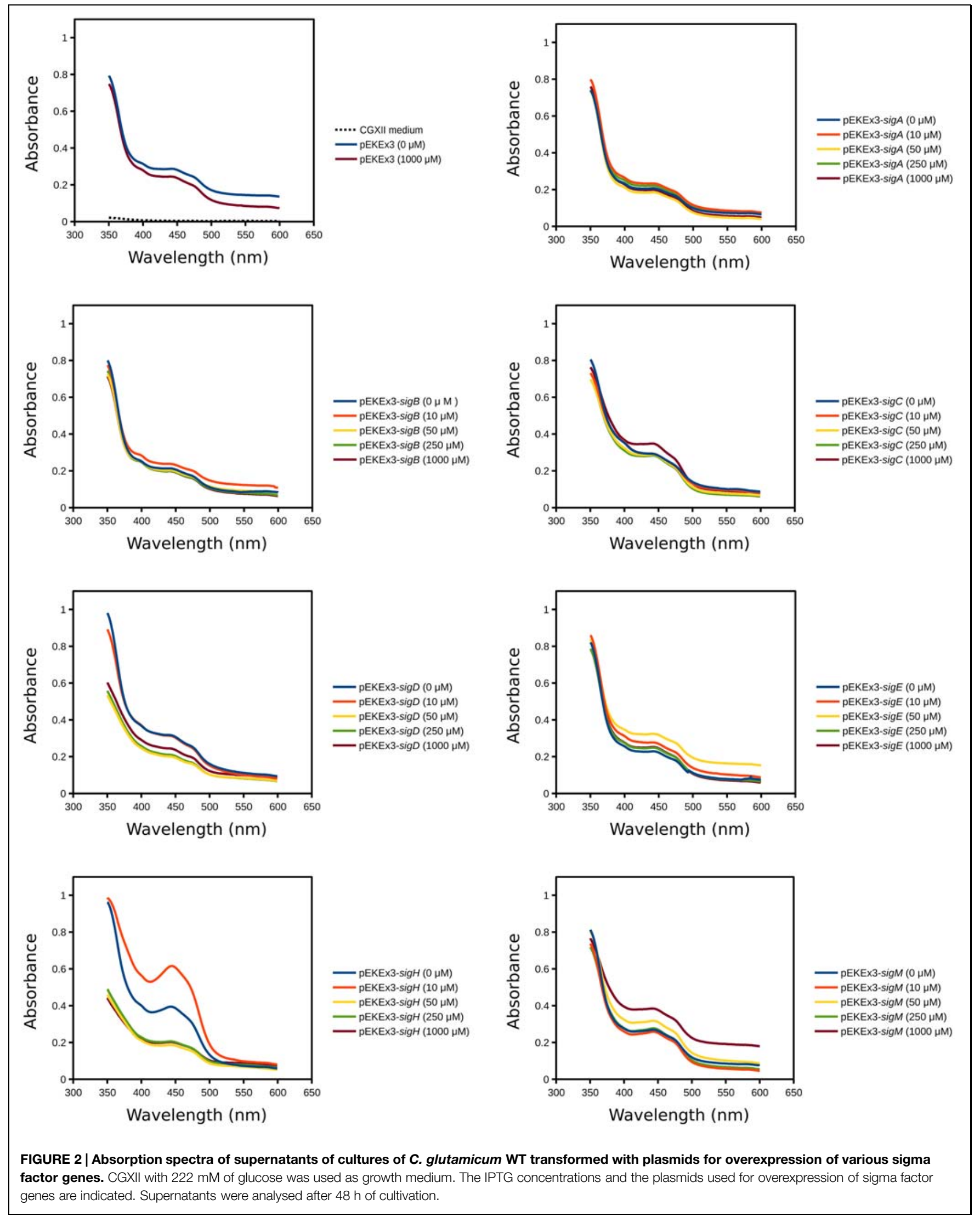




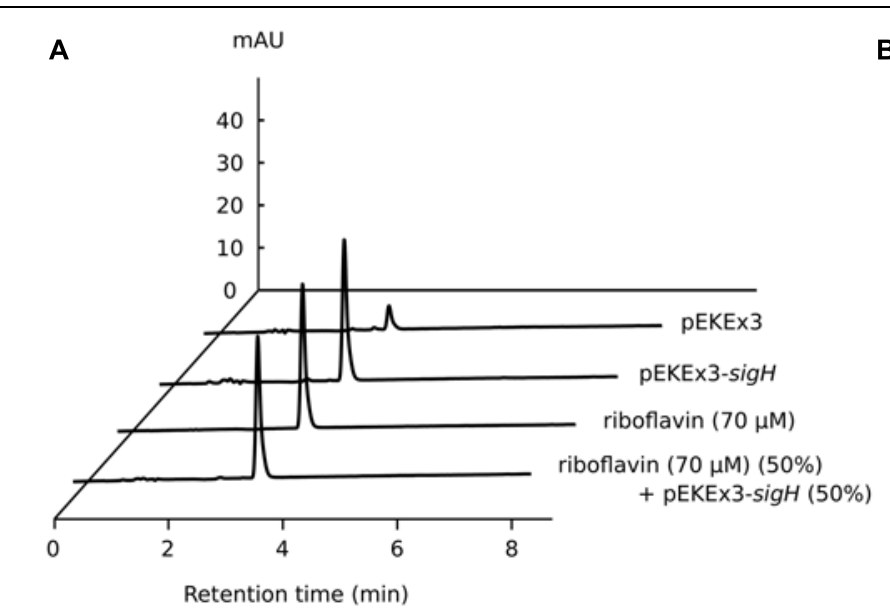

FIGURE 3 | Analysis of supernatants of C. glutamicum WT(pEKEx3-sigH) cultures by (A) high performance liquid chromatography (HPLC) and (B) spectrophotometry. (A) HPLC chromatograms of supernatants of C. glutamicum WT(pEKEX3) and WT(pEKEX3-sigH) after $48 \mathrm{~h}$ in CGXII with $222 \mathrm{mM}$ of glucose. Expression of sigH was induced by addition of $15 \mu \mathrm{M}$ of

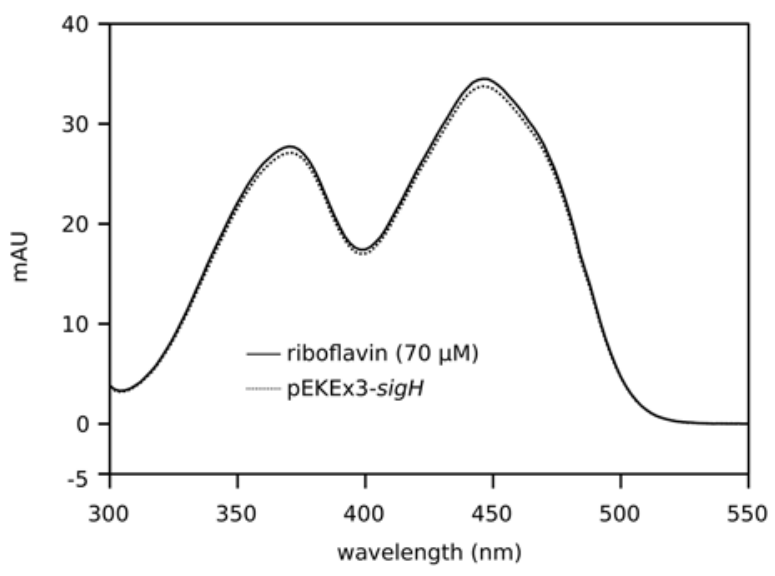

IPTG at the start of the cultivation. A standard of pure riboflavin $(70 \mu \mathrm{M})$ and a $50 \% / 50 \%$ mixture of this standard and the supernatant of the culture of WT(pEKEx3-sigh) are given for comparison. Absorbance at $450 \mathrm{~nm}$ is shown. (B) Spectra recorded at the retention time of $3.2 \mathrm{~min}$ of the HPLC samples of C. glutamicum WT(pEKEx3-sigH) and the riboflavin standard from (A).
A

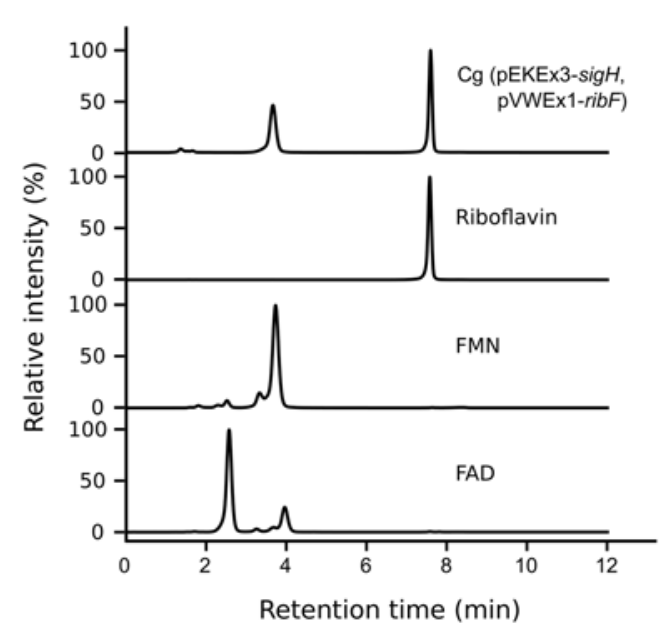

B

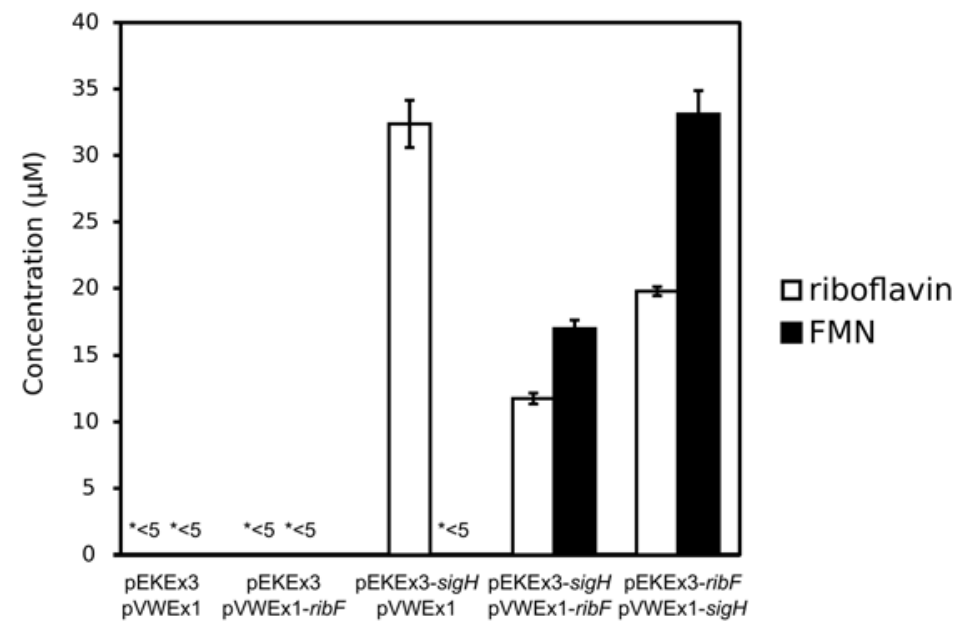

FIGURE 4 | Analysis of supernatants of C. glutamicum WT(pEKEx3-sigH, pVWEx1-ribF) cultures by HPLC (A) and riboflavin and FMN concentrations in supernatants of various strains (B). (A) HPLC chromatograms of supernatants of C. g/utamicum WT(pEKEx3-sigH, pWWEx1-ribF) after $48 \mathrm{~h}$ in CGXII with $222 \mathrm{mM}$ of glucose. Expression of sigH was induced by addition of $100 \mu \mathrm{M}$ of IPTG in the middle of the exponential growth phase $(O D \sim 10)$. Standards of commercial preparations of riboflavin, FMN and FAD are given for comparison. Absorbance at $450 \mathrm{~nm}$ is shown. (B) Concentrations of riboflavin and FMN in supernatants of cultures of C. glutamicum WT transformed with the indicated plasmids. FAD was not detectable $(<5 \mu \mathrm{M})$ in the analyzed supernatants. ${ }^{*}<5$ indicates that riboflavin or FMN in these supernatants were below $5 \mu \mathrm{M}$. Biological triplicates. et al., 2005a; Larisch et al., 2007; Nakunst et al., 2007; Ehira et al., 2008, 2009; Park et al., 2008; Pátek and Nešvera, 2011; Busche et al., 2012; Holátko et al., 2012; Toyoda et al., 2015). Here, we have determined the growth response of C. glutamicum to sigma factor gene overexpression. Overexpression of every sigma factor gene slowed growth in glucose minimal medium, however, the effects varied. The smallest effects were found when the general sigma factor genes $\operatorname{sig} A$ and $\operatorname{sig} B$ or the genes for SigE and SigM were overexpressed (Figure 1). Overexpression of sigC in glucose minimal medium with $250 \mu \mathrm{M}$ IPTG reduced the growth rate by about one third (Figure 1). The growth was severely inhibited (about half-maximal inhibition with IPTG concentrations as low as $15 \mu \mathrm{M}$ ) as consequence of overexpressing sigD or sigH. The functions and promoter selectivities of SigC and SigD remain to be studied, however, it is known that deletion of sigD retarded growth under microaerobic conditions (Ikeda et al., 2009). The observed growth inhibitory effects of overexpressing sigD or sigC described 
TABLE 2 | DNA microarray analysis of genes differentially expressed upon sigH overexpression.

\begin{tabular}{|c|c|c|c|c|c|c|}
\hline Gene ID ${ }^{a}$ & Gene name ${ }^{a}$ & Function of protein ${ }^{a}$ & \multicolumn{2}{|c|}{$M$-value $^{\mathrm{b}}$} & \multicolumn{2}{|c|}{$P$-value ${ }^{c}$} \\
\hline cg0186 & & Putative methylated-DNA-protein-cysteine methyltransferase & 1.3 & 1.1 & 4.3E-4 & $3.8 \mathrm{E}-3$ \\
\hline cg0614 & & Hypothetical protein & 2.9 & 2.2 & $2.1 \mathrm{E}-3$ & $5.6 \mathrm{E}-3$ \\
\hline $\operatorname{cg} 0616$ & $f d h D$ & Putative formate dehydrogenase, FdhD-family & 2.7 & 3.4 & $4.8 \mathrm{E}-4$ & 1.1E-2 \\
\hline $\operatorname{cg} 1081$ & & ABC-type putative daunorubicin transporter, ATPase subunit & 1.2 & 1.4 & $1.6 \mathrm{E}-2$ & $2.9 \mathrm{E}-2$ \\
\hline $\operatorname{cg} 1127$ & & Putative mycothiol S-conjugate amidase & 1.3 & 2.6 & $1.3 \mathrm{E}-3$ & 2.7E-3 \\
\hline $\operatorname{cg} 1386$ & fixA & Putative electron transfer flavoprotein, beta subunit & 1.1 & 2.0 & $1.7 \mathrm{E}-3$ & $1.4 \mathrm{E}-2$ \\
\hline $\operatorname{cg} 1397$ & $\operatorname{trm} U$ & tRNA (5-methylaminomethyl-2-thiouridylate)-methyltransferase & 1.5 & 1.7 & $6.6 \mathrm{E}-4$ & $4.8 \mathrm{E}-3$ \\
\hline $\operatorname{cg} 1398$ & & Conserved hypothetical protein & 1.7 & 2.4 & 1.9E-2 & 2.3E-2 \\
\hline $\operatorname{cg} 1688$ & & Putative proteasome component & 2.2 & 2.2 & $2.0 \mathrm{E}-4$ & 7.9E-3 \\
\hline $\operatorname{cg} 1689$ & & Conserved hypothetical protein & 2.3 & 3.0 & $9.5 \mathrm{E}-4$ & $1.4 \mathrm{E}-2$ \\
\hline $\operatorname{cg} 1709$ & $m s h C$ & Putative 1-D-myo-inosityl-2-amino-2-deoxy-alpha-D-glucopyranoside-L-cysteine ligase & 2.9 & 1.9 & $1.2 \mathrm{E}-4$ & 1.5E-3 \\
\hline $\operatorname{cg} 1764$ & sufB & FeS assembly membrane protein, SufB-family & 1.2 & 1.0 & $1.8 \mathrm{E}-3$ & $9.1 \mathrm{E}-3$ \\
\hline $\operatorname{cg} 1776$ & tal & Transaldolase & 1.0 & 1.7 & $1.6 \mathrm{E}-2$ & $1.2 \mathrm{E}-3$ \\
\hline $\operatorname{cg} 1778$ & $z w f$ & Glucose-6-phosphate 1-dehydrogenase & 1.2 & 2.0 & 4.1E-3 & 4.6E-3 \\
\hline $\operatorname{cg} 1779$ & opcA & Glucose-6-phosphate 1-dehydrogenase subunit & 1.6 & 1.2 & $1.5 \mathrm{E}-3$ & $5.0 \mathrm{E}-2$ \\
\hline $\operatorname{cg} 1796$ & $r i b X$ & Conserved putative membrane protein, RibX-like & 1.2 & 1.7 & $6.7 \mathrm{E}-3$ & 3.5E-3 \\
\hline $\operatorname{cg} 1797$ & $\mathrm{ribH}$ & Riboflavin synthase, beta chain & 1.7 & 1.3 & $6.4 \mathrm{E}-5$ & 1.7E-3 \\
\hline $\operatorname{cg} 1798$ & ribA & Putative GTP cyclohydrolase II/3,4-dihydroxy-2-butanone-4-phosphatesynthase & 2.0 & 1.0 & 4.6E-5 & 8.0E-3 \\
\hline $\operatorname{cg} 2296$ & hisl & Phosphoribosyl-AMP cyclohydrolase & 1.2 & 1.1 & $3.1 \mathrm{E}-3$ & $8.4 \mathrm{E}-3$ \\
\hline cg2297 & hisF & Imidazole glycerol phosphate synthase subunit HisF & 1.4 & 1.4 & $1.6 \mathrm{E}-2$ & 9.7E-4 \\
\hline cg2411 & & Conserved hypothetical protein, HesB/YadR/YfhF family & 2.1 & 2.8 & $4.0 \mathrm{E}-4$ & $4.2 \mathrm{E}-4$ \\
\hline cg2423 & lipA & Lipoyl synthetase & 1.6 & 1.7 & $1.9 \mathrm{E}-4$ & 8.5E-3 \\
\hline $\operatorname{cg} 2538$ & & Alkanal monooxygenase (FMN-linked) & 3.3 & 4.2 & 7.9E-4 & $1.6 \mathrm{E}-5$ \\
\hline $\operatorname{cg} 2644$ & clpP2 & Endopeptidase Clp, proteolytic subunit & 1.1 & 1.1 & $7.6 \mathrm{E}-4$ & $9.4 \mathrm{E}-5$ \\
\hline cg2661 & & Putative dithiol-disulfide isomerase & 1.5 & 1.9 & $1.1 \mathrm{E}-4$ & 4.7E-3 \\
\hline $\operatorname{cg} 2665$ & & Hypothetical protein & 1.4 & 1.4 & $4.6 \mathrm{E}-3$ & $7.8 \mathrm{E}-3$ \\
\hline cg2762 & murl & Glutamate racemase & 2.0 & 2.4 & $5.0 \mathrm{E}-2$ & $2.4 \mathrm{E}-2$ \\
\hline cg2835 & & Putative acetyltransferase & 1.0 & 3.3 & 4.7E-2 & 2.6E-2 \\
\hline $\operatorname{cg} 2838$ & & Putative dithiol-disulfide isomerase & 3.6 & 3.2 & $3.9 \mathrm{E}-6$ & $2.9 \mathrm{E}-3$ \\
\hline cg3236 & $m s r A$ & Protein-methionine-S-oxide reductase & 1.4 & 3.4 & $3.4 \mathrm{E}-3$ & 1.1E-2 \\
\hline cg3372 & & Conserved hypothetical protein & 1.1 & 1.3 & $2.5 \mathrm{E}-5$ & $4.2 \mathrm{E}-2$ \\
\hline cg3405 & & NADPH:quinone reductase $\mathrm{Zn}$-dependent oxidoreductase & 2.6 & 2.8 & $7.8 \mathrm{E}-4$ & 1.7E-2 \\
\hline $\operatorname{cg} 3422$ & $\operatorname{tr} x B$ & Thioredoxin reductase & 1.8 & 2.2 & $3.1 \mathrm{E}-4$ & $1.8 \mathrm{E}-4$ \\
\hline cg3423 & $\operatorname{tr} x \mathrm{C}$ & Thioredoxin & 1.5 & 2.1 & $4.1 \mathrm{E}-4$ & $6.8 \mathrm{E}-5$ \\
\hline cg3424 & cWIM & $\mathrm{N}$-acetylmuramoyl-L-alanine amidase & 1.3 & 1.7 & $8.2 \mathrm{E}-3$ & $1.4 \mathrm{E}-2$ \\
\hline
\end{tabular}

${ }^{\mathrm{a} G e n e} I D$, gene name and function of proteins are given according to CoryneRegNet (http://coryneregnet.de/). ${ }^{\mathrm{b}}$ Relative RNA levels in a strain overexpressing sigH as compared to the empty vector control are shown as log 2 values (M-values). To induce sigH overexpression either 10 or $15 \mu M$ IPTG were added. ${ }^{c} P$-values were determined by Student's $t$-test. 
in this study suggested that these sigma factors are not negligible and proper expression levels of those sigma factors are important for expression of genes required for fast growth in glucose minimal medium.

Analysis of the supernatants of C. glutamicum overexpressing sigma factor genes (Figure 2) revealed that only sigH overexpression led to the production of a colored compound, which was identified to be riboflavin (Figure 3). Moreover, sigH overexpression slowed growth (Figure 1). Regulation by SigH in C. glutamicum is known to some detail. The alternative sigma factor SigH is controlled by anti-sigma factor RshA, which possibly shuts down the SigH-dependent stress response after the cells have overcome the stress condition (Busche et al., 2012). SigH has been shown to be involved in expression of $\operatorname{tr} x B$ encoding thioredoxin reductase (Kim et al., 2005a), $w h c E$ encoding transcriptional regulator WhiB (Kim et al., 2005b), sigM (Nakunst et al., 2007), small antisense RNA gene arnA (Zemanová et al., 2008), the F0F1-ATP synthase operon atpBEFHAGDC (Barriuso-Iglesias et al., 2013), mycothiol peroxidase gene $m p x$ ( $\mathrm{Si}$ et al., 2015a), mycothiol S-conjugate amidase gene $m c a$ (Si et al., 2014), and methionine sulfoxide reductase A gene $m s r A$ (Si et al., 2015b). In addition, promoter selectivity of SigH has been studied using an in vitro transcription system (Holátko et al., 2012). Moreover, the SigH regulon has been studied by DNA microarray and ChIP-chip analyses involving deletion and overexpression of $\operatorname{sigH}$ as well as deletion of the anti-sigma factor gene $r s h A$ (Ehira et al., 2009; Busche et al., 2012; Toyoda et al., 2015). The strong growth inhibition as a result of overexpression of $\operatorname{sigH}$ shown here is commensurate with the described functions of SigH. In our DNA microarray analysis, 50 genes were upregulated when sigH overexpression was induced with 10 and $15 \mu \mathrm{M}$ IPTG (Table 2). These data generally agree with previous data on control by SigH (Ehira et al., 2009; Busche et al., 2012; Toyoda et al., 2015). Notably, overexpression of $s i g H$ in the wild type, i.e., in the presence of its anti-sigma factor RshA, elicited similar expression changes as deletion of $r \operatorname{sh} A$, i.e., 43 out of 50 genes upregulated as consequence of $\operatorname{sigH}$ overexpression were also upregulated in the absence of anti-sigma factor RshA (Busche et al., 2012). A motif search with the 50 upregulated genes (Table 2) using UniProt database (http://www.uniprot.org/) identified putative iron sulfur cluster-containing proteins encoded by cg0616 (fdhD), cg1432 (ilvD), cg2206 (ispG) and cg2423 (lipA), proteins predicted to contain NAD $(\mathrm{P}) \mathrm{H}$ binding sites encoded by $\mathrm{cg} 0184$, cg0616 (fdhD), cg1778 (zwf), cg2194 ( $m t r)$, and cg3405, and proteins with predicted FMN/FAD binding sites encoded by cg0616 (fdhD), cg1386 (fixA), cg2194 ( $m$ tr), cg2538 and $\operatorname{cg} 3422$ $(\operatorname{tr} x B)$. Iron sulfur clusters are sensitive to oxidative stress and $\mathrm{NAD}(\mathrm{P}) \mathrm{H}, \mathrm{FMN}, \mathrm{FAD}$ are important electron donor/acceptors. Upregulation of genes related to riboflavin synthesis under $\operatorname{sigH}$ overexpression observed here (Table 2) was consistent with a very recent ChIP-chip data on SigH-dependent promoters in C. glutamicum R (Toyoda et al., 2015).

In C. glutamicum, riboflavin biosynthesis was shown to be dependent on ribA-encoded bifunctional GTP cyclohydrolase II/3,4-dihydroxy-2-butanone 4-phosphate synthase, since in its absence efficient growth required supplemental riboflavin
(Takemoto et al., 2014). Uptake of supplemental riboflavin occurs via the transporter RibM (Vogl et al., 2007) and both RibM protein levels and ribM mRNA were reduced in FMN-rich cells due to the FMN-riboswitch (Takemoto et al., 2014). The FMNriboswitch has been observed in an RNAseq-based analysis of the transcriptional landscape of C. glutamicum (Pfeifer-Sancar et al., 2013) and control by the FMN-riboswitch was shown to involve Rho and RNase E/G (Takemoto et al., 2015). However, riboflavin biosynthesis appears not to be controlled by the FMNriboswitch. Instead, transcription of the riboflavin biosynthesis operon depends on SigH and deletion of $r s h A$ and overexpression of $\operatorname{sigH}$ resulted in riboflavin secretion as recently reported in the $r$ shA deletion mutant (Figure 3; Toyoda et al., 2015). Neither FMN nor FAD accumulated under these conditions, which may be explained by the fact that ribF expression has not been found to be influenced by deletion of $r s h$ and overexpression of sigH (Busche et al., 2012; Toyoda et al., 2015) (Table 2).

Riboflavin concentrations in supernatants of wild-type C. glutamicum cultures were low, but traces may be present (Figure 3). Eremothecium ashbyii and Ashbya gossypii are known as natural producers of riboflavin (Osman and Soliman, 1963; Kato and Park, 2011) and Bacillus subtilis, E. coli, and Corynebacterium ammoniagenes were selected and/or metabolically engineered to overproduce riboflavin (Koizumi et al., 2000; Stahmann et al., 2000; Lin et al., 2014). The role of extracellular riboflavin is still unclear. However, iron limitation resulted in riboflavin secretion by Candida guilliermondii and other organisms (Enari and Kauppinen, 1961; Neilands, 2014) and it has been suggested that excreted riboflavin may play an important role for ferric iron reduction and iron acquisition (Worst et al., 1998; Crossley et al., 2007). A riboflavin export system is currently unknown.

This study showed that FMN overproduction by C. glutamicum is possible. Simultaneous overexpression of $\operatorname{sigH}$ and ribF resulted in the secretion of riboflavin and FMN into the medium, while FAD was not detected (Figure 4). Currently, FMN is synthesized chemically involving phosphorylation of riboflavin. However, FMN preparations typically contain 25\% impurities such as isomeric riboflavin phosphates, riboflavin cyclophosphates, and riboflavin bisphosphates, which can act as antimetabolites and thus be toxic (Abbas and Sibirny, 2011). Enzyme-catalyzed biotransformation of riboflavin and metaphosphate using a crude enzyme preparation from genetically engineered C. ammoniagenes yielded $40 \mu \mathrm{M}$ of FMN without concomitant FAD formation (Nakagawa et al., 1995). Fermentative production of $0.5 \mathrm{mM}$ of FMN using genetically engineered Candida famata has also been reported (Yatsyshyn et al., 2010). Although conversion from riboflavin to FMN in the present study was not complete and titers were not high, a proof-of-principle demonstration of fermentative FMN production by C. glutamicum could be shown. Future work will address conversion of FMN to FAD and strain development to improve riboflavin, FMN and FAD yields and productivities.

This and work by others (Toyoda et al., 2015) showed that analysis of sigma factor gene overexpression in C. glutamicum wild type helped discover the potential of this 
bacterium for riboflavin production. In Synechocystis sp. PCC 6803 , overexpression of sigE activated expression of sugar catabolic genes and increased polyhydroxybutyrate (PHB) during nitrogen starvation (Osanai et al., 2011, 2013). SigE from Synechocystis sp. PCC 6803 and SigB from C. glutamicum belong to group 2 sigma factors and SigB from C. glutamicum positively regulates glucose catabolism genes (Ehira et al., 2008). Overexpression of SigF in Mycobacterium smegmatis enhanced carotenoid biosynthesis by upregulating the carotenoid biosynthesis operon (Kumar et al., 2015), however, C. glutamicum does not possess the same type of sigma factor. Future studies will have to establish if and to what extent the approach of

\section{References}

Abbas, C. A., and Sibirny, A. A. (2011). Genetic control of biosynthesis and transport of riboflavin and flavin nucleotides and construction of robust biotechnological producers. Microbiol. Mol. Biol. Rev. 75, 321-360. doi: 10.1128/MMBR.00030-0

Barile, M., Brizio, C., De Virgilio, C., Delfine, S., Quagliariello, E., and Passarella, S. (1997). Flavin adenine dinucleotide and flavin mononucleotide metabolism in rat liver-the occurrence of FAD pyrophosphatase and FMN phosphohydrolase in isolated mitochondria. Eur. J. Biochem. 249, 777-785. doi: 10.1111/j.14321033.1997.00777.x

Barriuso-Iglesias, M., Barreiro, C., Sola-Landa, A., and Martín, J. F. (2013). Transcriptional control of the F0F1-ATP synthase operon of Corynebacterium glutamicum: sigmaH factor binds to its promoter and regulates its expression at different $\mathrm{pH}$ values. Microb. Biotechnol. 6, 178-188. doi: 10.1111/17517915.12022

Blombach, B., Arndt, A., Auchter, M., and Eikmanns, B. J. (2009). L-Valine production during growth of pyruvate dehydrogenase complex- deficient Corynebacterium glutamicum in the presence of ethanol or by inactivation of the transcriptional regulator SugR. Appl. Environ. Microbiol. 75, 1197-1200. doi: 10.1128/AEM.02351-08

Blombach, B., Schreiner, M. E., Holátko, J., Bartek, T., Oldiges, M., and Eikmanns, B. J. (2007). L-valine production with pyruvate dehydrogenase ComplexDeficient Corynebacterium glutamicum. Appl. Environ. Microbiol. 73, 20792084. doi: 10.1128/AEM.02826-06

Brune, I., Brinkrolf, K., Kalinowski, J., Pühler, A., and Tauch, A. (2005). The individual and common repertoire of DNA-binding transcriptional regulators of Corynebacterium glutamicum, Corynebacterium efficiens, Corynebacterium diphtheriae and Corynebacterium jeikeium deduced from the complete genome sequences. BMC Genomics 6:86. doi: 10.1186/1471-2164-6-86

Bückle-Vallant, V., Krause, F. S., Messerschmidt, S., and Eikmanns, B. J. (2014). Metabolic engineering of Corynebacterium glutamicum for 2-ketoisocaproate production. Appl. Microbiol. Biotechnol. 98, 297-311. doi: 10.1007/s00253-0135310-2

Burkovski, A. (2008). Corynebacteria: Genomics and Molecular Biology. Norfolk, Horizon Scientific Press.

Busche, T., Silar, R., Pičmanová, M., Pátek, M., and Kalinowski, J. (2012). Transcriptional regulation of the operon encoding stress-responsive ECF sigma factor SigH and its anti-sigma factor RshA, and control of its regulatory network in Corynebacterium glutamicum. BMC Genomics 13:445. doi: 10.1186/14712164-13-445

Cho, B.-K., Kim, D., Knight, E. M., Zengler, K., and Palsson, B. O. (2014). Genome-scale reconstruction of the sigma factor network in Escherichia coli: topology and functional states. BMC Biol. 12:4. doi: 10.1186/17417007-12-4

Cho, S., Yang, S., and Rhie, H. (2012). The gene encoding the alternative thymidylate synthase ThyX is regulated by sigma factor SigB in Corynebacterium glutamicum ATCC 13032. FEMS Microbiol. Lett. 328, 157-165. doi: 10.1111/j.1574-6968.2011. 02494.x

Crossley, R. A., Gaskin, D. J. H., Holmes, K., Mulholland, F., Wells, J. M., Kelly, D. J., et al. (2007). Riboflavin biosynthesis is associated with assimilatory sigma factor gene overexpression is transferable to classically obtained or metabolically engineered C. glutamicum strains and/or to other bacteria. This may also pertain to "awakening" silent or orphan gene clusters relevant for secondary metabolite production, e.g., silent antibiotic biosynthesis gene clusters.

\section{Acknowledgments}

We acknowledge support for the Article Processing Charge by the Deutsche Forschungsgemeinschaft and the Open Access Publication Fund of Bielefeld University.

ferric reduction and iron acquisition by Campylobacter jejuni. Appl. Environ. Microbiol. 73, 7819-7825. doi: 10.1128/AEM.01919-07

Dondrup, M., Albaum, S. P., Griebel, T., Henckel, K., Jünemann, S., Kahlke, T., et al. (2009). EMMA 2-a MAGE-compliant system for the collaborative analysis and integration of microarray data. BMC Bioinformatics 10:50. doi: 10.1186/1471-2105-10-50

Eberhardt, D., Jensen, J. V. K., and Wendisch, V. F. (2014). L-citrulline production by metabolically engineered Corynebacterium glutamicum from glucose and alternative carbon sources. AMB Express 4:85. doi: 10.1186/s13568-014-0085-0

Eggeling, L., and Bott, M. (2005). Handbook of Corynebacterium glutamicum. Boca Raton, FL: CRC Press. doi: 10.1201/9781420039696

Eggeling, L., and Bott, M. (2015). A giant market and a powerful metabolism: L-lysine provided by Corynebacterium glutamicum. Appl. Microbiol. Biotechnol. 99, 3387-3394. doi: 10.1007/s00253-015-6508-2.

Ehira, S., Shirai, T., Teramoto, H., Inui, M., and Yukawa, H. (2008). Group 2 sigma factor SigB of Corynebacterium glutamicum positively regulates glucose metabolism under conditions of oxygen deprivation. Appl. Environ. Microbiol. 74, 5146-5152. doi: 10.1128/AEM.00944-08

Ehira, S., Teramoto, H., Inui, M., and Yukawa, H. (2009). Regulation of Corynebacterium glutamicum heat shock response by the extracytoplasmicfunction sigma factor SigH and transcriptional regulators HspR and HrcA. J. Bacteriol. 191, 2964-2972. doi: 10.1128/JB.00112-09

Enari, T., and Kauppinen, V. (1961). Interaction of cobalt and iron in riboflavine production of Candida guilliermondii. Acta Chem. Scand. 15, 1513-1516. doi: 10.3891/acta.chem.scand.15-1513

Feklístov, A., Sharon, B. D., Darst, S. A., and Gross, C. A. (2014). Bacterial sigma factors: a historical, structural, and genomic perspective. Annu. Rev. Microbiol. 68, 357-376. doi: 10.1146/annurev-micro-092412-155737

Gibson, D. G., Young, L., Chuang, R.-Y., Venter, J. C., Hutchison, C. A. III, and Smith, H. O. (2009). Enzymatic assembly of DNA molecules up to several hundred kilobases. Nat. Methods 6, 343-345. doi: 10.1038/nmeth.1318

Holátko, J., Silar, R., Rabatinová, A., Sanderová, H., Halada, P., Nešvera, J., et al. (2012). Construction of in vitro transcription system for Corynebacterium glutamicum and its use in the recognition of promoters of different classes. Appl. Microbiol. Biotechnol. 96, 521-529. doi: 10.1007/s00253-012-4336-1

Hwang, J.-H., Hwang, G.-H., and Cho, J.-Y. (2008). Effect of increased glutamate availability on L-ornithine production in Corynebacterium glutamicum. J. Microbiol. Biotechnol. 18, 704-710.

Ikeda, M., Baba, M., Tsukumoto, N., Komatsu, T., Mitsuhashi, S., and Takeno, S. (2009). Elucidation of genes relevant to the microaerobic growth of Corynebacterium glutamicum. Biosci. Biotechnol. Biochem. 73, 2806-2808. doi: 10.1271/bbb. 90741

Ikeda, M., and Katsumata, R. (1999). Hyperproduction of tryptophan by Corynebacterium glutamicum with the modified pentose phosphate pathway. Appl. Environ. Microbiol. 65, 2497-2502.

Jensen, J. V. K., and Wendisch, V. F. (2013). Ornithine cyclodeaminase-based proline production by Corynebacterium glutamicum. Microb. Cell Fact. 12, 63. doi: 10.1186/1475-2859-12-63

Kalinowski, J., Bathe, B., Bartels, D., Bischoff, N., Bott, M., Burkovski, A., et al. (2003). The complete Corynebacterium glutamicum ATCC 13032 genome sequence and its impact on the production of L-aspartate-derived amino acids and vitamins. J. Biotechnol. 104, 5-25. doi: 10.1016/S0168-1656(03)00154-8 
Kato, T., and Park, E. Y. (2011). Riboflavin production by Ashbya gossypii. Biotechnol. Lett. 34, 611-618. doi: 10.1007/s10529-011-0833-z

Kazmierczak, M. J., Wiedmann, M., and Boor, K. J. (2005). Alternative sigma factors and their roles in bacterial virulence. Microbiol. Mol. Biol. Rev. 69, 527-543. doi: 10.1128/MMBR.69.4.527-543.2005

Kim, T.-H., Kim, H.-J., Park, J.-S., Kim, Y., Kim, P., and Lee, H.-S. (2005a). Functional analysis of sigH expression in Corynebacterium glutamicum. Biochem. Biophys. Res. Commun. 331, 1542-1547. doi: 10.1016/j.bbrc. 2005.04.073

Kim, T.-H., Park, J.-S., Kim, H.-J., Kim, Y., Kim, P., and Lee, H.-S. (2005b). The whcE gene of Corynebacterium glutamicum is important for survival following heat and oxidative stress. Biochem. Biophys. Res. Commun. 337, 757-764. doi: 10.1016/j.bbrc.2005.09.115

Kirk-Othmer. (1984). Encyclopedia of Chemical Technology, Vitamin to Zone Refining Vol. 24 Edn. New York: Wiley-Interscience.

Koizumi, S., Yonetani, Y., Maruyama, A., and Teshiba, S. (2000). Production of riboflavin by metabolically engineered Corynebacterium ammoniagenes. Appl. Microbiol. Biotechnol. 53, 674-679. doi: 10.1007/s002539900295

Krause, F. S., Blombach, B., and Eikmanns, B. J. (2010). Metabolic engineering of Corynebacterium glutamicum for 2-ketoisovalerate production. Appl. Environ. Microbiol. 76, 8053-8061. doi: 10.1128/AEM.01710-10

Kumar, S., Matange, N., Umapathy, S., and Visweswariah, S. S. (2015). Linking carbon metabolism to carotenoid production in mycobacteria using Raman spectroscopy. FEMS Microbiol. Lett. 362, 1-6. doi: 10.1093/femsle/ fnu048

Larisch, C., Nakunst, D., Hüser, A. T., Tauch, A., and Kalinowski, J. (2007). The alternative sigma factor SigB of Corynebacterium glutamicum modulates global gene expression during transition from exponential growth to stationary phase. BMC Genomics 8:4. doi: 10.1186/1471-2164-8-4

Lin, Z., Xu, Z., Li, Y., Wang, Z., Chen, T., and Zhao, X. (2014). Metabolic engineering of Escherichia coli for the production of riboflavin. Microb. Cell Fact. 13:104. doi: 10.1186/s12934-014-0104-5

Mimitsuka, T., Sawai, H., Hatsu, M., and Yamada, K. (2007). Metabolic engineering of Corynebacterium glutamicum for cadaverine fermentation. Biosci. Biotechnol. Biochem. 71, 2130-2135. doi: 10.1271/bbb.60699

Morbach, S., Sahm, H., and Eggeling, L. (1996). L-Isoleucine production with Corynebacterium glutamicum: further flux increase and limitation of export. Appl. Environ. Microbiol. 62, 4345-4351.

Nakagawa, S., Hagihara, T., Fujio, T., and Aisaka, K. (1995). Metaphosphatedependent phosphorylation of riboflavin to FMN by Corynebacterium ammoniagenes. Appl. Microbiol. Biotechnol. 43, 325-329. doi: 10.1007/BF00172833

Nakunst, D., Larisch, C., Hüser, A. T., Tauch, A., Pühler, A., and Kalinowski, J. (2007). The extracytoplasmic function-type sigma factor SigM of Corynebacterium glutamicum ATCC 13032 is involved in transcription of disulfide stress-related genes. J. Bacteriol. 189, 4696-4707. doi: 10.1128/JB.00382-07

Neilands, J. B. (2014). Microbial Iron Metabolism: A Comprehensive Treatise. New York: Academic Press.

Netzer, R., Krause, M., Rittmann, D., Peters-Wendisch, P. G., Eggeling, L., Wendisch, V. F., et al. (2004). Roles of pyruvate kinase and malic enzyme in Corynebacterium glutamicum for growth on carbon sources requiring gluconeogenesis. Arch. Microbiol. 182, 354-363. doi: 10.1007/s00203-0040710-4

Nováková, J., Izsáková, A., Grivalský, T., Ottmann, C., and Farkašovský, M. (2014). Improved method for high-efficiency electrotransformation of Escherichia coli with the large BAC plasmids. Folia Microbiol. (Praha) 59, 53-61. doi: 10.1007/s12223-013-0267-1

Osanai, T., Numata, K., Oikawa, A., Kuwahara, A., Iijima, H., Doi, Y., et al. (2013). Increased bioplastic production with an RNA polymerase sigma factor SigE during nitrogen starvation in Synechocystis sp. PCC 6803. DNA Res. 20, 525-535. doi: 10.1093/dnares/dst028

Osanai, T., Oikawa, A., Azuma, M., Tanaka, K., Saito, K., Hirai, M. Y., et al. (2011). Genetic engineering of group 2 sigma factor SigE widely activates expressions of sugar catabolic genes in Synechocystis species PCC 6803. J. Biol. Chem. 286, 30962-30971. doi: 10.1074/jbc.M111.231183

Osman, H. G., and Soliman, M. H. M. (1963). Biosynthesis of riboflavin (Vit. B2) by Eremothecium ashbyii. Arch. Mikrobiol. 46, 255-264. doi: 10.1007/BF00422187
Paget, M. S., and Helmann, J. D. (2003). The $\sigma 70$ family of sigma factors. Genome Biol. 4:203. doi: $10.1186 / \mathrm{gb}-2003-4-1-203$

Park, S.-D., Youn, J.-W., Kim, Y.-J., Lee, S.-M., Kim, Y., and Lee, H.S. (2008). Corynebacterium glutamicum sigmaE is involved in responses to cell surface stresses and its activity is controlled by the anti-sigma factor CseE. Microbiol. Read. Engl. 154, 915-923. doi: 10.1099/mic.0.2007/0 12690-0

Park, S. H., Kim, H. U., Kim, T. Y., Park, J. S., Kim, S.-S., and Lee, S. Y. (2014). Metabolic engineering of Corynebacterium glutamicum for L-arginine production. Nat. Commun. 5:4618. doi: 10.1038/ncomms5618

Pátek, M., and Nešvera, J. (2011). Sigma factors and promoters in Corynebacterium glutamicum. J. Biotechnol. 154, 101-113. doi: 10.1016/j.jbiotec.2011. 01.017

Peters-Wendisch, P. G., Schiel, B., Wendisch, V. F., Katsoulidis, E., Möckel, B. Sahm, H., et al. (2001). Pyruvate carboxylase is a major bottleneck for glutamate and lysine production by Corynebacterium glutamicum. J. Mol. Microbiol. Biotechnol. 3, 295-300.

Peters-Wendisch, P., Stolz, M., Etterich, H., Kennerknecht, N., Sahm, H., and Eggeling, L. (2005). Metabolic engineering of Corynebacterium glutamicum for L-serine production. Appl. Environ. Microbiol. 71, 7139-7144. doi: 10.1128/AEM.71.11.7139-7144.2005

Pfeifer-Sancar, K., Mentz, A., Rückert, C., and Kalinowski, J. (2013). Comprehensive analysis of the Corynebacterium glutamicum transcriptome using an improved RNAseq technique. BMC Genomics 14:888. doi: 10.1186/1471-2164-14-888

Polen, T., Schluesener, D., Poetsch, A., Bott, M., and Wendisch, V. F. (2007). Characterization of citrate utilization in Corynebacterium glutamicum by transcriptome and proteome analysis. FEMS Microbiol. Lett. 273, 109-119. doi: 10.1111/j.1574-6968.2007.00793.x

Radmacher, E., Vaitsikova, A., Burger, U., Krumbach, K., Sahm, H., and Eggeling, L. (2002). Linking central metabolism with increased pathway flux: L-valine accumulation by Corynebacterium glutamicum. Appl. Environ. Microbiol. 68 , 2246-2250. doi: 10.1128/AEM.68.5.2246-2250.2002

Sambrook, J. (2001). Molecular Cloning: A Laboratory Manual, 3rd Edn. Cold Spring Harbor, NY: Cold Spring Harbor Laboratory Press.

Schneider, J., Eberhardt, D., and Wendisch, V. F. (2012). Improving putrescine production by Corynebacterium glutamicum by fine-tuning ornithine transcarbamoylase activity using a plasmid addiction system. Appl. Microbiol. Biotechnol. 95, 169-178. doi: 10.1007/s00253-012-3956-9

Schneider, J., and Wendisch, V. F. (2010). Putrescine production by engineered Corynebacterium glutamicum. Appl. Microbiol. Biotechnol. 88, 859-868. doi: 10.1007/s00253-010-2778-x

Sharma, U. K., and Chatterii, D. (2010). Transcriptional switching in Escherichia coli during stress and starvation by modulation of $\sigma 70$ activity. FEMS Microbiol. Rev. 34, 646-657. doi: 10.1111/j.1574-6976.2010.00223.x

Si, M., Long, M., Chaudhry, M. T., Xu, Y., Zhang, P., Zhang, L., et al. (2014). Functional characterization of Corynebacterium glutamicum mycothiol S-conjugate amidase. PLoS ONE 9:e115075. doi: 10.1371/journal.pone.01 15075

Si, M., Xu, Y., Wang, T., Long, M., Ding, W., Chen, C., et al. (2015a). Functional characterization of a mycothiol peroxidase in Corynebacterium glutamicum that uses both mycoredoxin and thioredoxin reducing systems as proton donor for oxidative stress response. Biochem. J. doi: 10.1042/BJ20141080 [Epub ahead of print].

Si, M., Zhang, L., Chaudhry, M. T., Ding, W., Xu, Y., Chen, C., et al. (2015b). Corynebacterium glutamicum methionine sulfoxide reductase A uses both mycoredoxin and thioredoxin for regeneration and oxidative stress resistance. Appl. Environ. Microbiol. 81, 2781-2796. doi: 10.1128/AEM.04 221-14.

Stahmann, K. P., Revuelta, J. L., and Seulberger, H. (2000). Three biotechnical processes using Ashbya gossypii, Candida famata, or Bacillus subtilis compete with chemical riboflavin production. Appl. Microbiol. Biotechnol. 53, 509-516. doi: $10.1007 /$ s002530051649

Stansen, C., Uy, D., Delaunay, S., Eggeling, L., Goergen, J.-L., and Wendisch, V. F. (2005). Characterization of a Corynebacterium glutamicum lactate utilization operon induced during temperature-triggered glutamate production. Appl. Environ. Microbiol. 71, 5920-5928. doi: 10.1128/AEM.71.10.5920-59 28.2005 
Staroń, A., Sofia, H. J., Dietrich, S., Ulrich, L. E., Liesegang, H., and Mascher, T. (2009). The third pillar of bacterial signal transduction: classification of the extracytoplasmic function (ECF) $\sigma$ factor protein family. Mol. Microbiol. 74, 557-581. doi: 10.1111/j.1365-2958.2009.06870.x

Takemoto, N., Tanaka, Y., and Inui, M. (2015). Rho and RNase play a central role in FMN riboswitch regulation in Corynebacterium glutamicum. Nucleic Acids Res. 43, 520-529. doi: 10.1093/nar/gku1281

Takemoto, N., Tanaka, Y., Inui, M., and Yukawa, H. (2014). The physiological role of riboflavin transporter and involvement of FMN-riboswitch in its gene expression in Corynebacterium glutamicum. Appl. Microbiol. Biotechnol. 98, 4159-4168. doi: 10.1007/s00253-014-5570-5

Toyoda, K., Teramoto, H., Yukawa, H., and Inui, M. (2015). Expanding the regulatory network governed by the extracytoplasmic function sigma factor $\sigma \mathrm{H}$ in Corynebacterium glutamicum. J. Bacteriol. 197, 483-496. doi: 10.1128/JB.02248-14

Tripathi, L., Zhang, Y., and Lin, Z. (2014). Bacterial sigma factors as targets for engineered or synthetic transcriptional control. Front. Bioeng. Biotechnol. 2:33. doi: $10.3389 /$ fbioe. 2014.00033

van der Rest, M. E., Lange, C., and Molenaar, D. (1999). A heat shock following electroporation induces highly efficient transformation of Corynebacterium glutamicum with xenogeneic plasmid DNA. Appl. Microbiol. Biotechnol. 52, 541-545. doi: 10.1007/s002530051557

Vassylyev, D. G., Sekine, S., Laptenko, O., Lee, J., Vassylyeva, M. N., Borukhov, S., et al. (2002). Crystal structure of a bacterial RNA polymerase holoenzyme at 2.6 A resolution. Nature 417, 712-719. doi: 10.1038/nature752

Vogl, C., Grill, S., Schilling, O., Stülke, J., Mack, M., and Stolz, J. (2007). Characterization of riboflavin (Vitamin B2) transport proteins from Bacillus subtilis and Corynebacterium glutamicum. J. Bacteriol. 189, 7367-7375. doi: 10.1128/JB.00590-07

Vogt, M., Haas, S., Polen, T., van Ooyen, J., and Bott, M. (2015). Production of 2ketoisocaproate with Corynebacterium glutamicum strains devoid of plasmids and heterologous genes. Microb. Biotechnol. 8, 351-360. doi: 10.1111/17517915.12237

Watanabe, K., Teramoto, H., Suzuki, N., Inui, M., and Yukawa, H. (2013). Influence of SigB inactivation on Corynebacterium glutamicum protein secretion. Appl. Microbiol. Biotechnol. 97, 4917-4926. doi: 10.1007/s00253-0124586-y

Weber, H., Polen, T., Heuveling, J., Wendisch, V. F., and Hengge, R. (2005). Genome-wide analysis of the general stress response network in Escherichia coli: $\sigma$ S-dependent cenes, promoters, and sigma factor selectivity. J. Bacteriol. 187, 1591-1603. doi: 10.1128/JB.187.5.15911603.2005

Wendisch, V. F. (2003). Genome-wide expression analysis in Corynebacterium glutamicum using DNA microarrays. J. Biotechnol. 104, 273-285. doi: 10.1016/S0168-1656(03)00147-0

Worst, D. J. M., Gerrits, M., Vandenbroucke-Grauls, C. M. J. E., and Kusters, J. G. (1998). Helicobacter pylori ribBA-mediated riboflavin production is involved in iron acquisition. J. Bacteriol. 180, 1473-1479.

Yatsyshyn, V. Y., Fedorovych, D. V., and Sibirny, A. A. (2010). Medium optimization for production of flavin mononucleotide by the recombinant strain of the yeast Candida famata using statistical designs. Biochem. Eng. J. 49, 52-60. doi: 10.1016/j.bej.2009.11.010

Yukawa, H., and Inui, M. (eds). (2013). Corynebacterium glutamicum. Berlin: Springer Berlin. doi: 10.1007/978-3-64229857-8

Zemanová, M., Kaderábková, P., Pátek, M., Knoppová, M., Silar, R., and Nesvera, J. (2008). Chromosomally encoded small antisense RNA in Corynebacterium glutamicum. FEMS Microbiol. Lett. 279, 195-201. doi: 10.1111/j.15746968.2007.01024.x

Conflict of Interest Statement: The authors declare that the research was conducted in the absence of any commercial or financial relationships that could be construed as a potential conflict of interest.

Copyright $@ 2015$ Taniguchi and Wendisch. This is an open-access article distributed under the terms of the Creative Commons Attribution License (CC BY). The use, distribution or reproduction in other forums is permitted, provided the original author(s) or licensor are credited and that the original publication in this journal is cited, in accordance with accepted academic practice. No use, distribution or reproduction is permitted which does not comply with these terms. 